\title{
ELECTROCARDIOGRAPHIC ABNORMALITIES IN SEVERE MALNUTRITION
}

\author{
BY
}

\author{
LAURENCE B. ELLIS
}

\begin{abstract}
Approved for publication by the Office of the Chief Surgeon, European Theatre of Operations, U.S. Army
\end{abstract}
Received October 4, 1945

Just before and after V-E day a major medical problem in the European Theatre of Operations was the care of the great number of liberated Allied prisoners of war. Many of these were suffering from profound and prolonged malnutrition and the gravity of their physical condition, coupled with the great numbers involved, taxed the resources of the medical personnel caring for them. Numerous studies of various aspects of the physiological derangements of these soldiers have been made. This report is concerned with electrocardiographic findings in a small series of severely malnourished patients.

During the night of April 24, 1945, a trainload of 300 fresh casualties reached a U.S. Army General Hospital in England. Among these were a few severely malnourished liberated American prisoners of war. One of these, S/Sgt. A. A., appeared to be in such a critical state that it seemed unlikely that he would survive many hours. He was semi-stuporous, so weak he could hardly lift a hand, emaciated to a degree which has become all too familiar in photographs of the "Horror Camps," and suffering from intense diarrhœa. In spite of this he showed no œdema, his blood pressure was normal, and there was no clinical evidence of any vitamin deficiency. On admission it was noted that his pulse rate was 40 at the wrist and about 60 at the apex. This led to the taking of a cardiogram the following morning. Because of the striking findings in this record (Fig. 1), serial records were made on this patient and on 13 other liberated prisoners who were the most severely malnourished.

Some days after admission the first patient was interviewed by a reporter from the Stars and Stripes. Excerpts from this interview are reproduced here as they depict in graphic terms the conditions which produced the physical state of all of these men.

U.S. GENERAL HOSPITAL. The day the Nazis took S/Sgt. A.A., 106th Infantry Division squad-leader, prisoner, he weighed 210 pounds. Five months later, when liberated, he weighed 116 pounds. Considering the hell he's been through, he is coming along fine. But thanks to Himmler's S.S. he won't be walking around for some time. Here's what he told me :

"I was captured at St. Vith during the Rundstedt breakthrough. The Nazis searched me, and put me in a box-car with 42 other Yanks. They locked us in, sending us on our way to Germany.

"For five days and nights we didn't have any food or water. Luckily, some of our fellows still had a little water in their canteens-just enough to wet 43 parched mouths. We didn't dare drink the stuff; it was too precious. Added to this, the convoy we were in was being bombed and strafed continually by the Allies.

"We were sent to Camp 4b, 50 miles south of Berlin, and then to Camp 8a, near Gorlitz. Camp 4b was better to us. At least they didn't abuse us so much. Finally, they started us on the march because the Russians were advancing We got very little to eat on the march, but we usually got plenty of water. If there weren't any rivers or streams around the Russians or " Froggies " always brought it to us in buckets. If our guards caught them, they used to beat them, but most of them were smart. They used to leave the buckets on the side of the road and hide until we went by.

"I don't remember just how far we'd marched when the Yanks caught up with us. What I do remember, I was lying on top of a straw and manure pile when they found me, and I was pretty well gone."

Clinical abstracts on this and three other patients showing the most striking electrocardiographic changes follow. 


\section{CASE Notes}

Case 1. Staff Sgt. A. A., 29 years old, was captured on December 19, 1944, and released on April 13, 1945, eleven days before he entered the hospital. In addition to the account of his experiences quoted above, the following information is relevant. While a prisoner he had lived on the regular prison diet, which consisted of a sixth to an eighth of a loaf of bread, soup which occasionally contained a little meat, and a few potatoes daily. In addition, while marching, he received some jam and oneninth of a tin of meat weekly. In spite of his steady loss of weight he got along pretty well until February, since which time he was almost constantly on the march, averaging about 20 kilometres a day. Three days before he was libeıated he developed diarrhœa and abdominal cramps, and very rapidly went down hill from then on. He lost weight estimated at $100 \mathrm{lb}$. while a prisoner.

His past history was irrelevant; he was always a very healthy and vigorous person. Physical examination showed extreme emaciation, weakness, and semi-stupor. There was no œdema nor any evidence of vitamin deficiency. His tongue was normal and his skin though dirty showed no evidence of hyperkeratosis. The lungs were clear, the heart sounds were faint, and there was an apical systolic murmur. His blood pressure was $110 \mathrm{~mm}$. systolic and $60 \mathrm{~mm}$. diastolic.

Laboratory findings are shown in Table I. In addition the plasma albumin was 3.6 and globulin 2.0 per 100 c.c. on May 5. Urine analysis was normal except for a one-plus albumin on entry. A radiogram of the chest showed the lung fields to be clear and the heart unusually small, and one of the hands and forearms showed no evidence of decalcification. Cardiograms are shown in Fig. 1, 2 , and 3 .

TABLE I

Laboratory and Cardiographic Findings on Cases 1-4

\begin{tabular}{|c|c|c|c|c|c|c|c|c|c|}
\hline \multirow{2}{*}{$\begin{array}{l}\text { Case } \\
\text { No. }\end{array}$} & \multirow{2}{*}{ Date } & \multirow{2}{*}{$\begin{array}{l}\text { Hæmo- } \\
\text { globin } \\
\text { Grams } \\
\text { / } 100 \text { c.c. }\end{array}$} & \multirow{2}{*}{$\begin{array}{c}\text { Plasma } \\
\text { pro- } \\
\text { teins } \\
\text { Grams } \\
\text { /100 c.c. }\end{array}$} & \multirow{2}{*}{$\begin{array}{l}\text { Serum } \\
\text { Ca. } \\
\text { mg. } \\
/ 100 \\
\text { c.c. }\end{array}$} & \multirow{2}{*}{$\begin{array}{l}\text { Serum } \\
\mathrm{P} \\
\mathrm{mg} . \\
/ 100 \\
\text { c.c. }\end{array}$} & \multicolumn{4}{|c|}{ Electrocardiograms } \\
\hline & & & & & & $\begin{array}{l}\text { P-R } \\
\text { interval } \\
\text { sec. }\end{array}$ & $\begin{array}{c}\text { QRS } \\
\text { interval } \\
\text { sec. }\end{array}$ & $\begin{array}{c}\text { Q-T } \\
\text { interval * } \\
\text { sec. }\end{array}$ & $\mathrm{T}$ waves \\
\hline 1 & $\begin{array}{l}\text { April 25 } \\
\text { April 30 } \\
\text { May 3 } \\
\text { May } 5 \\
\text { May 8 } \\
\text { May 16 }\end{array}$ & $13 \cdot 3$ & $6 \cdot 2$ & $10 \cdot 2$ & $1 \cdot 5$ & $\begin{array}{l}0 \cdot 19-0 \cdot 20 \\
0 \cdot 19 \\
0 \cdot 19 \\
0 \cdot 19 \\
0 \cdot 18\end{array}$ & $\begin{array}{l}0 \cdot 12 \\
0 \cdot 11 \\
0 \cdot 09 \\
0.08 \\
0.07\end{array}$ & $\begin{array}{l}0 \cdot 70(+0 \cdot 28) \\
0.60(+0 \cdot 18) \\
0 \cdot 50(+0 \cdot 14) \\
0.38 \\
0.33\end{array}$ & $\begin{array}{l}\text { T II TIII up with low origin } \dagger \\
\text { T II TIII diphasic with low origin } \\
\text { T IV diphasic } \\
\text { T II T III diphasic } \\
\text { T II up T III inverted } \\
\text { All T waves upright }\end{array}$ \\
\hline 2 & $\mid \begin{array}{ll}\text { April 25 } \\
\text { April 28 } \\
\text { April 30 } \\
\text { May 5 } \\
\text { May } 8\end{array}$ & $13 \cdot 5$ & $\begin{array}{l}6 \cdot 7 \\
5 \cdot 1\end{array}$ & $\begin{array}{l}9 \cdot 5 \\
8 \cdot 7\end{array}$ & $\begin{array}{l}1 \cdot 6 \\
3 \cdot 3\end{array}$ & $\begin{array}{l}0 \cdot 21 \\
0 \cdot 18 \\
0 \cdot 22 \\
0 \cdot 18\end{array}$ & $\begin{array}{l}0.09 \\
0.08 \\
0.08 \\
0.08\end{array}$ & $\begin{array}{r}0.52(+0 \cdot 14) \\
0.54(+0 \cdot 16) \\
? 0 \cdot 50 \\
0.37\end{array}$ & $\begin{array}{l}\text { T I T II T IV bifid } \\
\text { T IV bifid } \\
\text { T IV bifid } \\
\text { All T waves upright }\end{array}$ \\
\hline 3 & $\begin{array}{l}\text { April 25 } \\
\text { April 29 } \\
\text { May } 3 \\
\text { May } 7 \\
\text { May } 16\end{array}$ & $\begin{array}{l}16 \cdot 8 \\
14 \cdot 9\end{array}$ & $8 \cdot 0$ & $9 \cdot 0$ & $1 \cdot 5$ & $\begin{array}{l}0 \cdot 12 \\
0 \cdot 12 \\
0 \cdot 12 \\
0 \cdot 12\end{array}$ & $\begin{array}{l}0.08 \\
0.08 \\
0.08 \\
0.07\end{array}$ & \begin{tabular}{|}
$? 0 \cdot 48(+0 \cdot 14)$ \\
$0 \cdot 48(+0 \cdot 14)$ \\
$0 \cdot 34(+0 \cdot 02)$ \\
$0 \cdot 32$
\end{tabular} & $\begin{array}{l}\text { T I isoelectric T II T III inverted } \\
\text { T II T III low origin } \\
\text { Slight depression S-T II and T III } \\
\text { All T waves upright }\end{array}$ \\
\hline 4 & $\begin{array}{c}\text { April 26 } \\
\text { May 5 } \\
\text { May 10 }\end{array}$ & $11 \cdot 1$ & $5 \cdot 5$ & $9 \cdot 1$ & $4 \cdot 0$ & $\begin{array}{l}0 \cdot 14 \\
0 \cdot 14\end{array}$ & $\begin{array}{l}0.07 \\
0.06\end{array}$ & $\begin{array}{l}0.38(+0.04) \\
0.33\end{array}$ & $\begin{array}{l}\text { Bifid T IV } \\
\text { Normal T waves }\end{array}$ \\
\hline
\end{tabular}

* Figures in parentheses refer to increase in Q-T above the maximum allowable by the standards of Ashman (1942). Measurements were made from start of QRS to return to the iso-electric level after the $T$ waves and may include $U$ waves.

$\dagger$ Ventricular premature beats every third beat.

His diarrhœa and cramps continued for about a week. For the first few days he was unable to take nourishment by mouth, except in extremely small quantities. He was given 2 units of plasma and 1000 c.c. of 5 per cent glucose in normal saline solution daily for three days. His temperature, which was sub-normal on entry, rose to 103 degrees by May 2 and remained up for several days, although at this time he had very greatly improved. He gained an estimated $20 \mathrm{lb}$. during this first week, this being largely due to improvement in hydration. On May 4 he was allowed to sit in a chair and by May 16 to walk short distances. He was given a 500 c.c. blood transfusion on May 8 .

Case 2. Pte. B. P., 23 years old, was captured on December 21, 1944, and released on April 13, 1945. His history was very similar to that of the first patient. The diet he was given was exactly the same and he suffered from severe diarrhœa for about two weeks before his release. Physical 

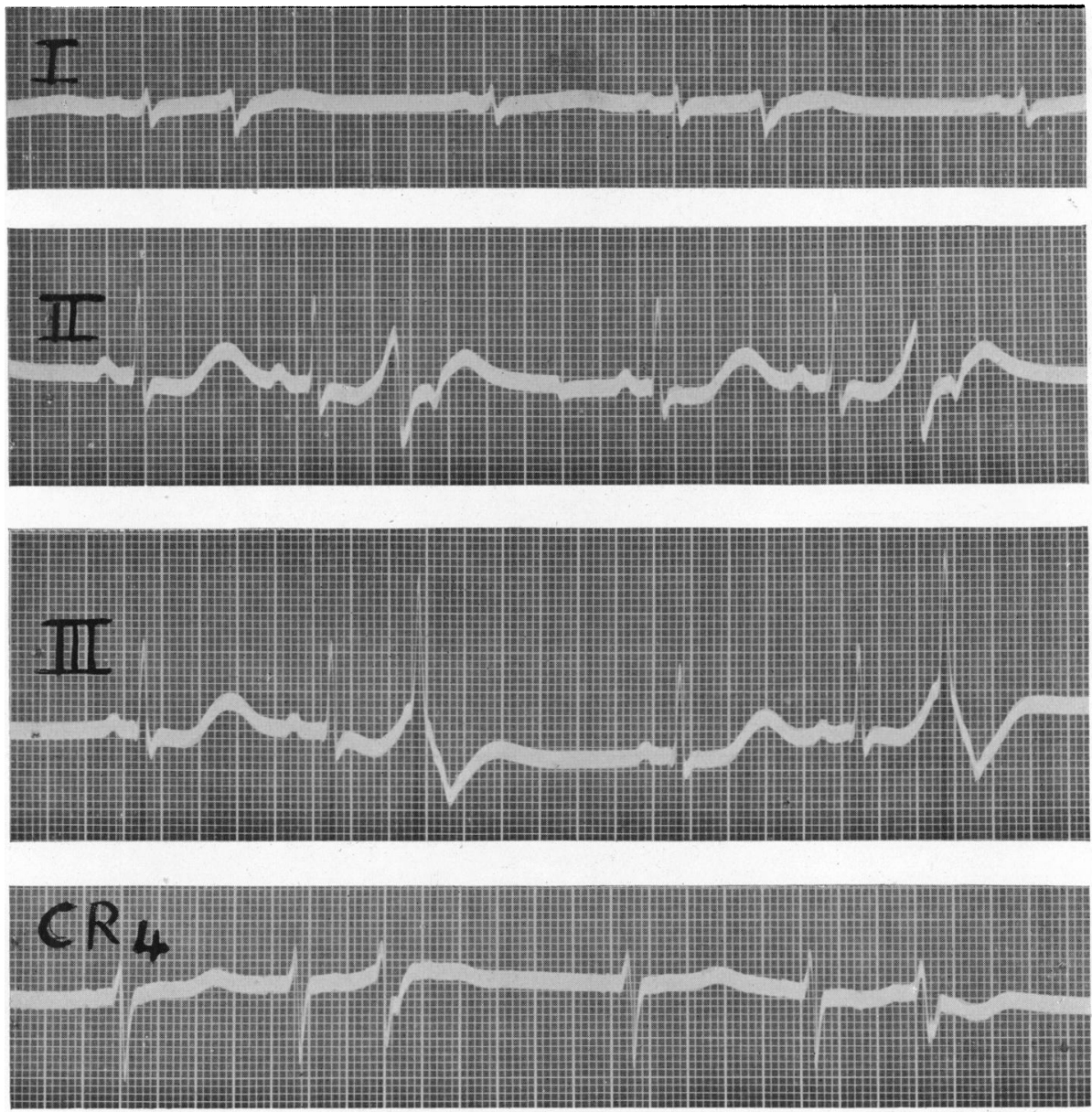

FIG. 1.-Electrocardiogram of Case 1. 25/4/45.

examination showed extreme malnutrition with an estimated loss of $64 \mathrm{lb}$. in weight during his confinement. He, however, was admitted as an ambulatory patient and was perfectly clear mentally. Physical examination on entry showed no œdema nor signs of vitamin deficiency. The heart was normal on examination, with normal sounds and no murmurs. Blood pressure was 110/70.

Laboratory findings are shown in Table I. In addition the urine analysis was normal, except for a one-plus albumin on entry. The plasma albumin was 4.1 on April 25 and 3.5 on May 5, and the globulin 2.6 and 2.1 per 100 c.c. on the same dates. A radiogram of his heart showed it to be rather small, and one of his hands and forearms showed no evidence of decalcification. Fig. 4 shows the cardiograms.

By April 30 he was much better and his diarrhœa had ceased. He was eating well, as he had since the beginning of his stay in hospital, and never required any intravenous fluid administration. On April 30 he developed some œdema of the ankles which persisted for about ten days. On this date also he noted that he had cramps of the hands and legs, and when he tried to write, his right hand went into spasm. Examination revealed carpo-pedal spasm after exercising his hands or feet and a positive Trousseau sign but a negative Chvostek sign. There were some fibrillary twitchings in the forearms. These signs persisted for about four days. At this time his blood calcium was normal, he was well hydrated and there was no clinical evidence of alkalosis, but the carbon dioxide combining power of the blood could not be done. His improvement continued thereafter in an uninterrupted manner, except that on May 16 he developed mild jaundice which was interpreted as being due to infectious hepatitis. This persisted for about a week only.

Case 3. Cpl. R. D., 25 years old, was captured on December 19, 1944, and released April 16, 1945. His history was much like the others except that he had not been forced to undergo any marching during the months before his release. He had had diarrhœa for about a week before his release. Upon entry he appeared to be in fair physical condition but had lost $30 \mathrm{lb}$. in weight. The blood 

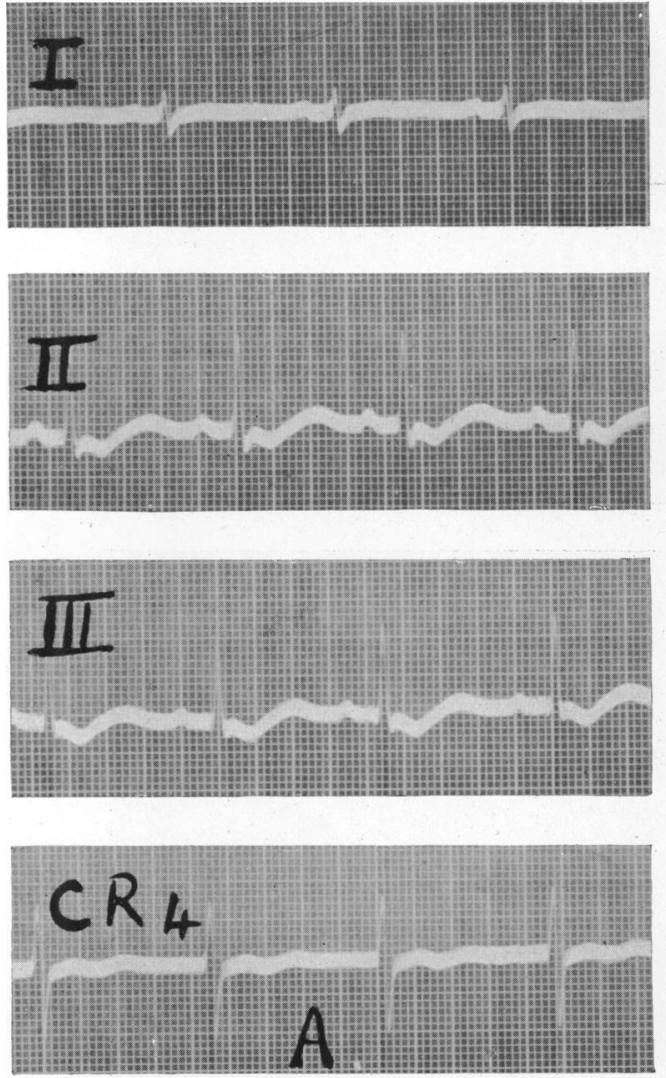
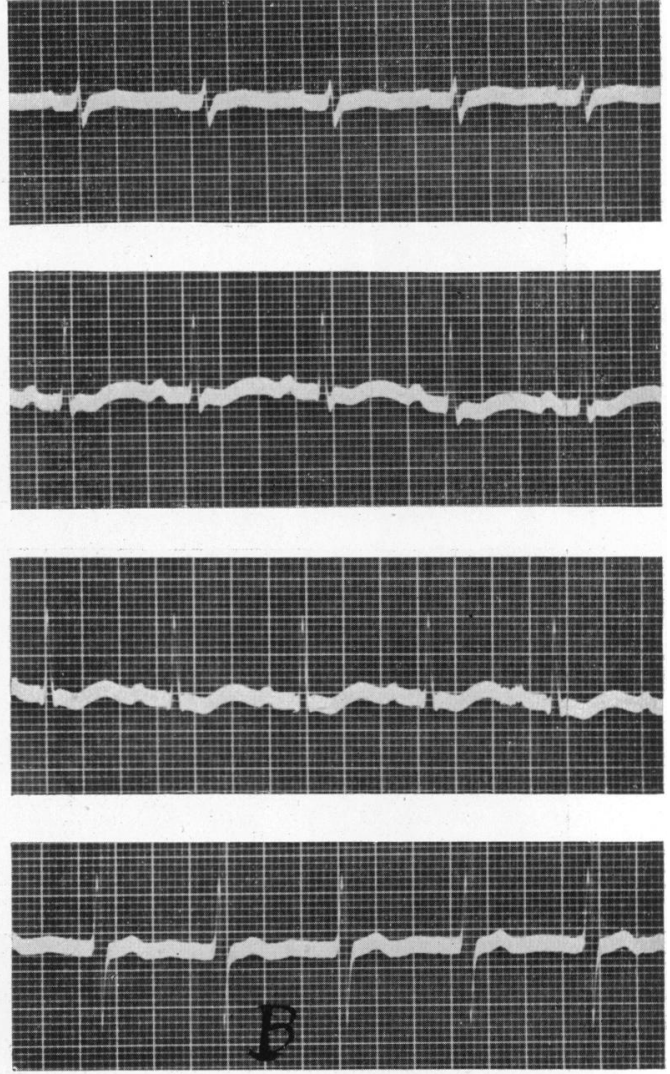

Fig. 2.-Later electrocardiograms of Case 1. (A) $30 / 4 / 45$. (B) $3 / 5 / 45$.

pressure was $90 / 50$ and the pulse rate ranged between 100 and 120 . There was no œdema and no clinical evidence of vitamin deficiency. Examination of the heart was normal.

Besides the laboratory findings shown on Table $I$, the urine analysis was normal and a radiogram of the heart showed it to be rather small. The cardiograms are shown in Fig. 5.

On April 27 his clinical condition was worse. He became very weak and developed nausea and vomiting and his blood pressure became unobtainable by the auscultatory method, but was estimated at about $80 \mathrm{~mm}$. systolic by palpation. He was given 2 units of plasma and 1000 c.c. of 5 per cent glucose in normal saline solution. This parenteral treatment was continued daily for four days. By May 2 he was much better and his blood pressure had risen to 120/70. He was then eating well without any more vomiting and his diarrhœa had practically ceased. His improvement after this continued uninterruptedly.

Case 4. Pte. J. B., 25 years old, was captured January 8, 1945 and released April 20, 1945. His story was similar to the others. He was marched for about 25 kilometres a day during the two weeks just before liberation and during this time also suffered from diarrhœa. In addition he gave a story of having had intermittent swelling of the hands and feet and around his eyes from March until shortly before he was admitted. He lost $55 \mathrm{lb}$. in weight during his confinement. Physical examination except for his emaciation was essentially normal. Examination of his heart revealed normal sounds and no murmurs were heard. The blood pressure was 120/70. There was no œdema and no clinical evidence of vitamin deficiency.

Laboratory findings are shown in Table I. In addition examination of the urine was negative except for a minimal amount of albumin on entry. The plasma albumin was 3.7 and the globulin 1.8 per 100 c.c. on April 26. A radiogram of the heart showed it to be well within normal limits. His cardiograms are shown in Fig. 6.

He ran a temperature for several days ranging from 103 to 104 degrees, with no evidence of any infection. His course in the hospital was uneventful and consisted of steady improvement. 

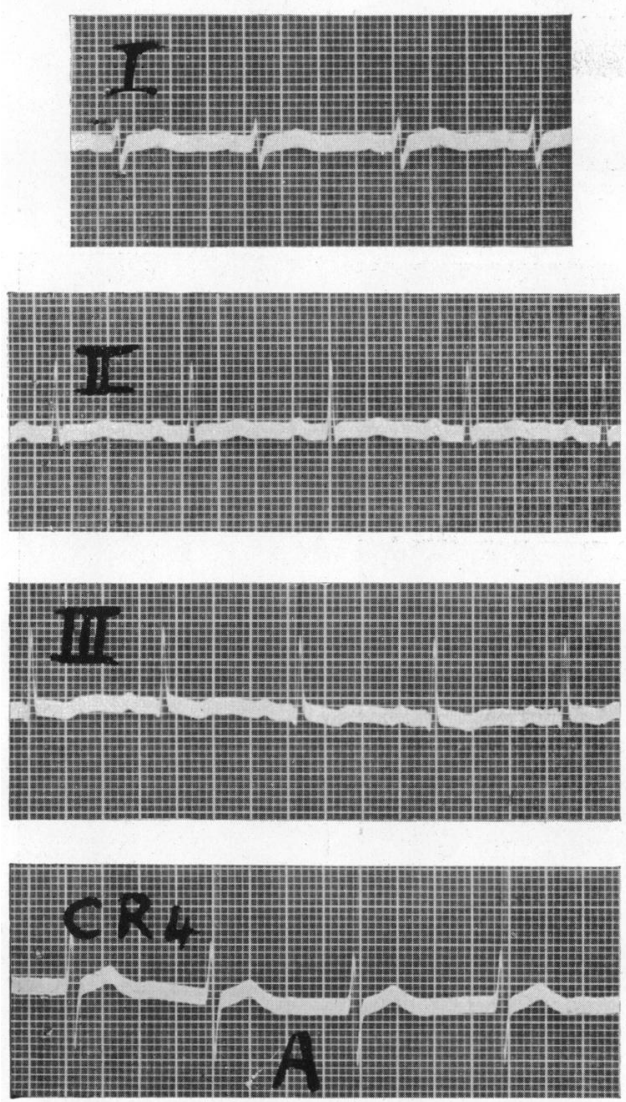

Fig. 3.-Later electrocardiograms of Case 1. (A) $8 / 5 / 45$. (B) $16 / 5 / 45$.
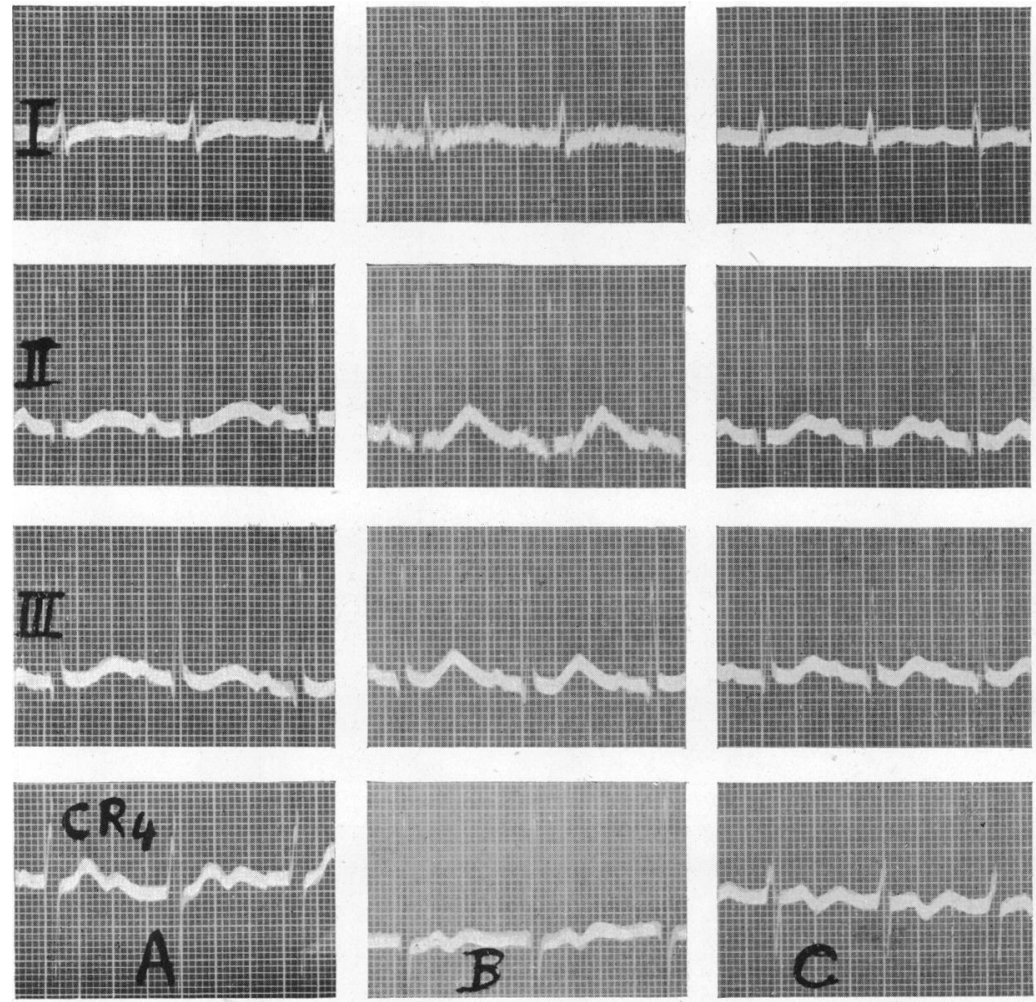
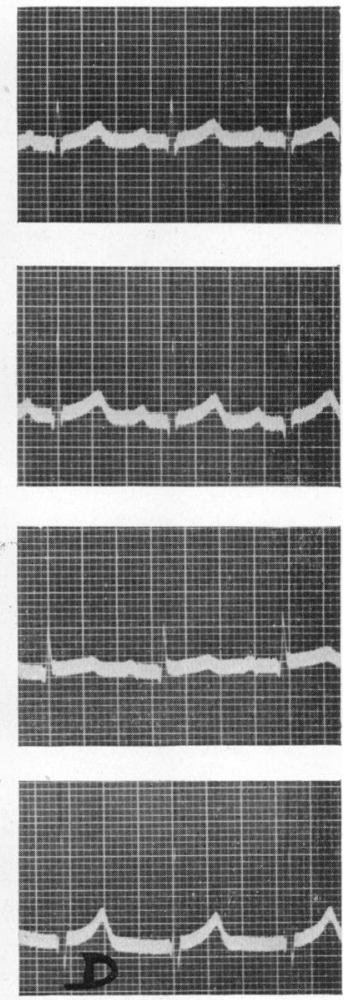

Fig. 4.-Electrocardiograms of Case 2. (A) $25 / 4 / 45$. (B) $28 / 4 / 45$. (C) $30 / 4 / 45$. (D) $8 / 5 / 45$. 

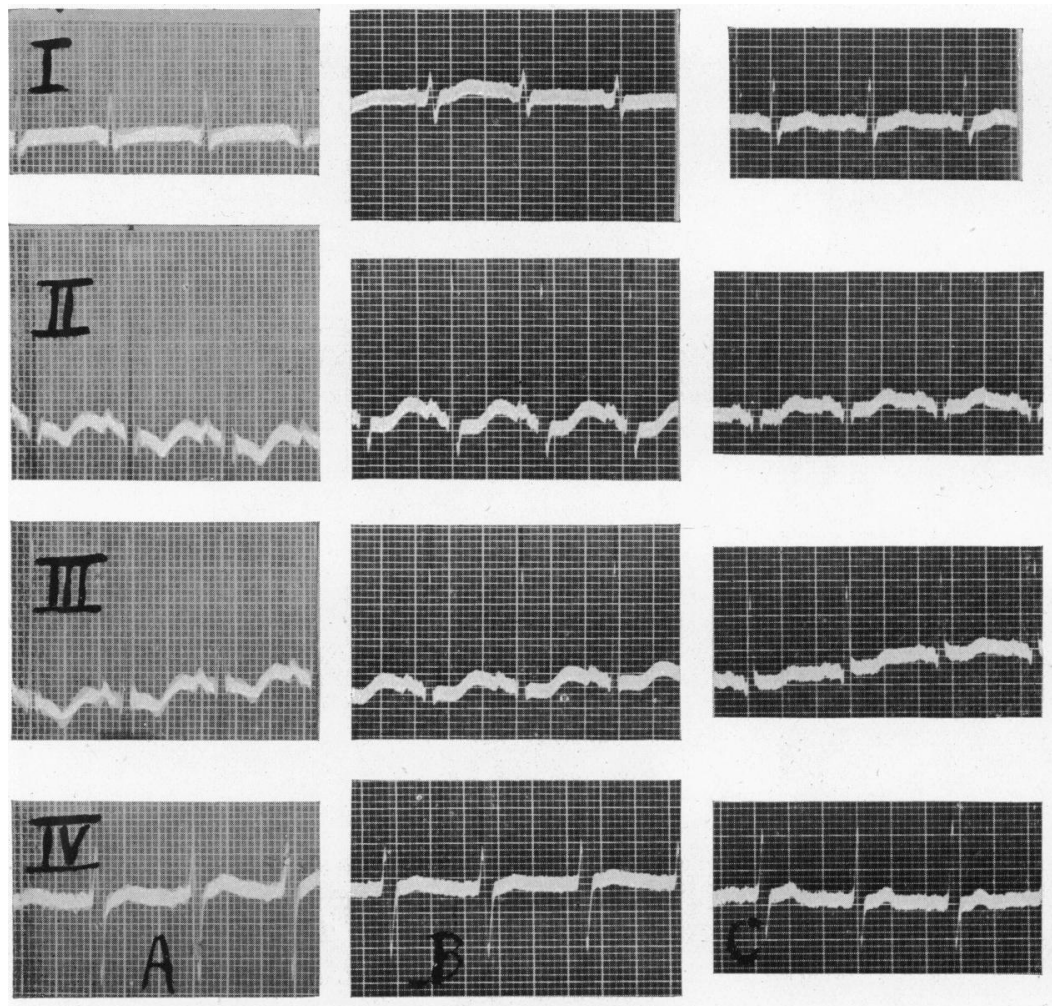

Fig. 5.-Electrocardiograms of Case 3. (A) $29 / 4 / 45$. (B) $3 / 5 / 45$. (C) $7 / 5 / 45$. (D) $16 / 5 / 45$.
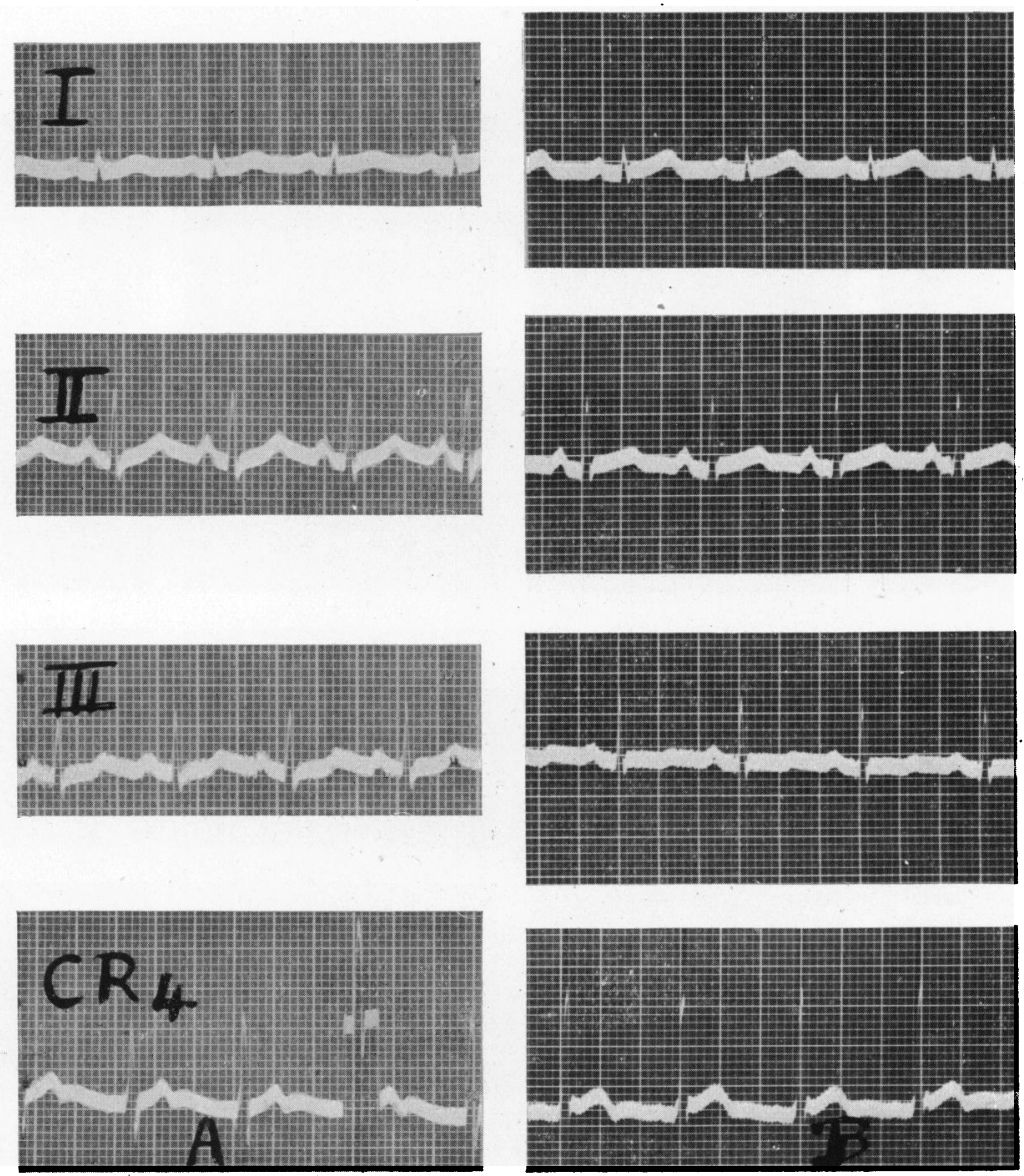

Fig. 6.-Electrocardiograms of Case 4. (A) 26/4/45. (B) $10 / 5 / 45$. 


\section{COMMENT}

The clinical story and physical findings in all four of these patients were essentially the same, varying only in degrees of severity. In no instance was there clinical evidence of vitamin deficiency. All were severely malnourished and dehydrated on admission and were suffering from diarrhœa. No patient had any symptoms or signs of cardiac or peripheral vascular disability, except Case 3, in whom a marked drop in blood pressure and tachycardia developed, accompanied by great weakness, but no other signs of shock. One patient had had moderate intermittent œdema prior to admission but showed none while in the hospital; another developed mild œdema after several days in hospital. In both instances this was considered to be nutritional in origin. In all four cases improvement after the first few days was steady. All showed rather small hearts by roentgenographic examination, and the cardiac findings on physical examination in each were normal. Most of them tended to run a raised temperature without any evidence of infection, which is an extremely common finding among the very undernourished patients. Of interest is the tetany which Case 2 developed without evidence of hypocalcæmia or alkalosis. Treatment other than that described in the case reports consisted of increasing amounts of food by mouth, including milk, eggs, and cereals with an addition of meat after some days. All patients were given 6 multi-vitamin capsules daily which provided a total daily intake of 15,000 U.S.P. units of vitamin A, 1200 U.S.P. units of vitamin D, $6.0 \mathrm{mg}$. of thiamin chloride, $9.0 \mathrm{mg}$. of riboflavin, $225 \mathrm{mg}$. of ascorbic acid, and $60 \mathrm{mg}$. of nicotinamide. In addition Cases 1 and 3 were given $30 \mathrm{mg}$. of thiamin and $50 \mathrm{mg}$. of nicotinamide intramuscularly daily for the first three or four days. (The parenteral nicotinamide was given in relatively small dosage because an adequate supply of this substance was not available at this time.) No digitalis or other specific cardiac medication was given.

\section{ELECTROCARDIOGRAPHIC FINDINGS}

The serial cardiograms on the four patients are shown in Fig. 1 to 6 . The most striking feature is the unusual $\mathrm{T}$ waves. The duration of these deflections, as measured from the initial phase of the QRS complex to the final return to the isoelectric level, is greatly lengthened, and the final phase in all the early records is positive and usually well marked. This may represent a $U$ wave, unusually large in the early tracings, which diminishes or disappears with improvement. The "bifid" $T$ waves occurring in Cases 2 and 4 suggest this as well as the progressive changes in the fourth leads in the other two cases. However, in many of the records it is impossible to say that the entire complex is not $\mathrm{T}$ wave. For the sake of convenience and comparison the total duration of this interval has been expressed as the " $\mathrm{Q}-\mathrm{T}$ interval," In two patients the $\mathrm{P}-\mathrm{R}$ interval was slightly and inconstantly prolonged; in addition, in Case 1, a widening of the QRS complex occurred.

In all four patients the cardiograms had returned to normal within 14 to 21 days.

Cardiograms were taken in 10 additional severely malnourished soldiers. None had symptoms or signs of cardiovascular disability or of vitamin deficiency.

One showed a prolongation of the Q-T interval of $0.02 \mathrm{sec}$. above the maximum allowable for normal persons, and low amplitude of all $\mathrm{T}$ waves, with a return to normal within one week All other cardiograms were within normal limits.

\section{Discussion}

The electrocardiographic abnormalities exhibited by these four patients are unusual and tend to follow a common pattern, the most striking and constant feature being an unusually great prolongation of the $\mathrm{Q}-\mathrm{T}$ interval or large $\mathrm{U}$ waves accompanying abnormal $\mathrm{T}$ waves. All of these patients were suffering from severe undernourishment and in addition were dehydrated, as judged from their obvious clinical condition and by the evidence of hæmodilution in Cases 1, 2 and 3, following treatment in the hospital (See Table 1).

None of these patients or any others among more than 400 personally observed showed any clinical evidence of vitamin deficiency. Observers who have studied very large numbers of persons who underwent chronic starvation under similar circumstances in Europe are agreed that clinical vitamin deficiencies are not common (Chapman, Meiklejohn, Pollack, personal communications, 1945). 
Cardiographic abnormalities occur in beriberi, which is considered to be due to a lack of thiamin; Weiss and Wilkins (1937) found in a large series of patients studied that such abnormalities were present in 93 per cent of the cases. In 79 per cent the Q-T interval was prolonged beyond the maximum allowed by the Cheer-Li standard $(0.38 \mathrm{sec}$.) and in 45 per cent it was greater than that permitted by the Shepley-Hallaran standard $(0.43 \mathrm{sec}$.). Other changes noted consisted of lowering or inversion of $T$ waves and minor changes in the QRS complexes.

Whether deficiencies in other vitamins lead to alterations in the electrocardiogram is not settled, but it was considered unlikely by Weiss and Wilkins. However, Rachmilewitz and Braun (1944) reported on two patients with severe diarrhœa who were "admitted in a state of severe deficiency." The first showed inversion of the T waves, and the second a well-marked prolongation of the Q-T interval. They attributed this to nicotinic acid deficiency since improvement occurred coincidentally with nicotinic acid administration. Feil (1936) previously had found the Q-T interval to be frequently prolonged in pellagra with a return to normal upon recovery. Usually this shortening of the Q-T interval, which occurred with improvement, ranged from 0.02 to $0.06 \mathrm{sec}$, but the maximum was $0.12 \mathrm{sec}$. In addition Feil described inversion of $T$ waves and elevation or depression of the $S-T$ interval as being not uncommon. In neither of these two articles is the possibility excluded that other deficiencies than lack of the pellagra-preventive vitamin complex may have been responsible for the cardiographic findings. Since clinical avitaminosis states are usually associated with multiple deficiencies, particularly as regards the B complex, it is difficult to assess the role that the lack of individual vitamins play in producing the cardiographic abnormalities.

The cardiographic pattern observed in the cases of the present study bears little resemblance to the characteristic changes reported previously in association with avitaminosis. As stated, these patients also had no clinical evidence of the cardiovascular manifestations of beriberi. There was no peripheral vasodilatation, no cardiac enlargement or heart failure, and no polyneuritis. Pellagrous lesions were absent. As Weiss and Wilkins have observed, since the tendency to develop avitaminosis varies directly with metabolic rate, clinical beriberi is not likely to develop in conditions of starvation and inanition.

Although a disturbance of the electrolyte balance of these undernourished patients undoubtedly occurred, it was impossible in this study to investigate this adequately. Hypocalcæmia characteristically produces a prolongation of the Q-T interval which is not uncommonly very marked in degree (Ashman, 1942, and Barker, Johnston, and Wilson, 1937). Other cardiographic changes do not usually develop with low serum calcium levels. None of the four patients studied had a reduction in blood serum calcium values below normal, although it is of interest that Case 2 developed clinical tetany. Since the plasma proteins were not increased it is unlikely that there was an abnormal reduction in the ionized calcium levels.

Pathological and experimental conditions causing abnormalities of the blood potassium produce cardiographic changes. When the potassium level in the blood is increased in man or animals experimentally by the administration of potassium salts (Winkler, et al., 1938, and Chamberlain, et al., 1939) or clinically in renal failure or Addison's disease (Thomson, 1939, and Keith, et al., 1944) the cardiogram first shows an increased height of the T waves especially in the chest lead, with a narrow base and a " peaked" apex. With greater increases in the serum potassium level in experimental animals partial auriculo-ventricular block and intraventricular block occur. The T waves may also be lowered or inverted. The duration of electrical systole was slightly prolonged in three patients in uræmia with high serum potassium studied by Keith et al. (1944), but marked alterations in the Q-T intervals did not occur when this was produced experimentally (Chamberlain et al., 1939).

Conversely, in a patient suffering from familial periodic paralysis, reported by Stewart, Smith, and Milhorat (1940), transient abnormalities occurred in the cardiogram when the serum potassium was reduced, consisting of prolonged $\mathrm{P}-\mathrm{R}$ interval, widened $\mathrm{QRS}$ complex, and prolongation of the $\mathrm{Q}-\mathrm{T}$ interval with a depressed $\mathrm{S}-\mathrm{T}$ interval and a lowering of $\mathrm{T}$ waves.

The cardiograms of the malnourished patients show little in common with the changes occurring with high serum potassium, and the similarities with the abnormalities found in the patient with low blood potassium, although slightly greater, are not at all marked. Whether 
such similarity as exists is more than coincidental is merely conjectural since it was impossible to carry out blood potassium studies in these patients.

Post-mortem observations on patients dying of malnutrition (Meiklejohn, 1945, and Pollack, 1945) have revealed that the hearts are small and flabby with brownish pigmentation ; microscopically the muscle fibres show loss of striation. In those cases showing generalized œdema, particularly those who had received fluid and salt for some weeks before death, there was in addition evidence of inter- and intra-fibrillary œedema of the cardiac musculature.

\section{SUMmaRY AND CONCLUSIONS}

Case reports are presented on four patients suffering from severe and prolonged malnutrition in whom electrocardiographic abnormalities were observed. These cardiographic changes consisted of a marked prolongation of the Q-T interval, or unusually well-marked but not persistent $U$ waves, and less constantly, depression of the $S-T$ segment, alterations in $T$ waves, and increase in the P-R and QRS intervals.

Although the available evidence does not permit any certain conclusions to be drawn as to the causation of the cardiographic abnormalities occurring in malnourished persons, it is probable that they represent a composite picture due to prolonged protein and carbohydrate starvation and electrolyte imbalance. There was no evidence of a significant degree of anoxia of the cardiac muscle or of clinical avitaminosis. Vitamin deficiency, however, cannot be entirely ruled out as an ætiological factor in spite of the absence of clinical symptoms and signs. The fact that the cardiograms returned to normal within two to three weeks after the institution of an adequate therapeutic regime suggests that the changes are chiefly due to functional and not to structural causes.

We are indebted to the following for information supplied about the rarity of clinical signs of vitamin deficiency : Dr. A. P. Meiklejohn of U.N.R.R.A. from observations at the Belsen Concentration Camp, Lt.-Col. Herbert Pollack, A.U.S., from observations of liberated prisoners of war, and Dr. Carleton Chapman, U.S.P.H.S. and U.N.R.R.A., from observations in Greece and Jugoslavia : and to the two former for postmortem observations on patients dying from malnutrition.

\section{REFERENCES}

Ashman, R. (1942). Amer. Heart J., 23, 522.

Barker, P. S., Johnston, F. D., and Wilson, F. N. (1937). Ibid., 14, 82.

Chamberlain, F. L., Scudder, J., and Zwemer, R. L. (1939). Ibid., 18, 458.

Chapman, C. (1945). Personal communication.

Feil, H. (1936). Amer. Heart J., 11, 173.

Keith, N. M., Burchell, H. B., and Bagenstoss, A. H. (1944). I Ibid., 27, 817.

Meiklejohn, A. P. (1945). Personal communication.

Pollack, H. (1945). Personal communication.

Rachmilewitz, M., and Braun, K. (1944). Amer. Heart J., 27, 203 (1944) ; and Brit. Heart J., 7, 72.

Stewart, H. J., Smith, J. J., and Milhorat, A. T. (1940). Amer. J. med. Sc., 199, 789.

Thomson, W. A. R. (1939). Lancet, 1, 808.

Weiss, S., and Wilkins, R. W. (1937). Ann. intern. Med., 11, 104.

Winkler, A. W., Hoff, H. E., and Smith, P. K. (1938). Amer. J. Physiol., 124, 478. 